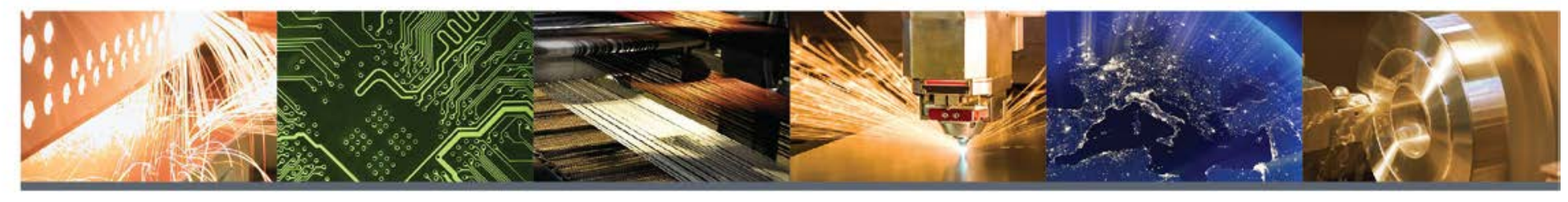

\title{
Carbon Fiber from Biomass
}

\author{
Anelia Milbrandt and Samuel Booth \\ Clean Energy Manufacturing Analysis Center \\ (CEMAC)
}

CEMAC is operated by the Joint Institute for Strategic Energy Analysis for the U.S. Department of Energy's Clean Energy Manufacturing Initiative.

\section{Technical Report}

NREL/TP-6A50-66386

September 2016

Contract No. DE-AC36-08GO28308 


\section{Carbon Fiber from Biomass}

\section{Anelia Milbrandt and Samuel Booth Clean Energy Manufacturing Analysis Center (CEMAC)}

Prepared under Task No. AM05.5820

CEMAC is operated by the Joint Institute for Strategic Energy Analysis for the U.S. Department of Energy's Clean Energy Manufacturing Initiative.

Clean Energy Manufacturing Analysis Center 15013 Denver West Parkway Golden, CO 80401 303-275-3000 www.manufacturingcleanenergy.org
Technical Report

NREL/TP-6A50-66386

September 2016

Contract No. DE-AC36-08G028308 


\section{NOTICE}

This report was prepared as an account of work sponsored by an agency of the United States government. Neither the United States government nor any agency thereof, nor any of their employees, makes any warranty, express or implied, or assumes any legal liability or responsibility for the accuracy, completeness, or usefulness of any information, apparatus, product, or process disclosed, or represents that its use would not infringe privately owned rights. Reference herein to any specific commercial product, process, or service by trade name, trademark, manufacturer, or otherwise does not necessarily constitute or imply its endorsement, recommendation, or favoring by the United States government or any agency thereof. The views and opinions of authors expressed herein do not necessarily state or reflect those of the United States government or any agency thereof.

Available electronically at SciTech Connect: $\underline{\text { http:/www.osti.gov/scitech }}$

Available for a processing fee to U.S. Department of Energy and its contractors, in paper, from:

U.S. Department of Energy

Office of Scientific and Technical Information

P.O. Box 62

Oak Ridge, TN 37831-0062

OSTI http://www.osti.gov

Phone: 865.576.8401

Fax: 865.576.5728

Email: reports@osti.gov

Available for sale to the public, in paper, from:

U.S. Department of Commerce

National Technical Information Service

5301 Shawnee Road

Alexandria, VA 22312

NTIS http://www.ntis.gov

Phone: 800.553 .6847 or 703.605 .6000

Fax: 703.605.6900

Email: orders@ntis.gov

Cover Photos: (left to right) iStock 2225189; iStock 16687273; Oak Ridge National Laboratory; iStock 24304597; iStock 26005993; iStock 2069560

NREL prints on paper that contains recycled content 


\section{Acknowledgments}

We would like to thank Joe Cresko and Brian Walker from the U.S. Department of Energy's Advanced Manufacturing Office (AMO) and Margaret Mann from the National Renewable Energy Laboratory (NREL) for their support and guidance throughout this project. Special thanks go to Mary Biddy from NREL for providing an estimate of carbon fiber production from lignocellulosic sugars, as well as for her review and valuable recommendations. We also thank Sujit Das from Oak Ridge National Laboratory, Jill Engel-Cox from the Clean Energy Manufacturing Analysis Center, and Brandon Hoffman from Allegheny Science and Technology Corporation for their review and helpful suggestions. 


\section{Nomenclature and Acronyms}

ACN

Btu

CELF

CF

GVL

$\mathrm{Ib}$

MJ

PAN

precursor

SLRP

SRM

THF

tonnes

tons acrylonitrile

British thermal units

Co-solvent Enhanced Lignocellulosic Fractionation carbon fiber

gamma valerolactone

pound

megajoule (= $948 \mathrm{Btu})$

polyacrylonitrile

the starting material used to make carbon fiber

Sequential Liquid-Lignin Recovery and Purification

solid rocket motor

tetrahydrofuran

metric tons

short tons 


\section{Executive Summary}

Carbon fiber (CF), known also as graphite fiber, is a lightweight, strong, and flexible material used in both structural (load-bearing) and non-structural applications (e.g., thermal insulation). The high cost of precursors (the starting material used to make CF, which comes predominately from fossil sources) and manufacturing have kept CF a niche market with applications limited mostly to high-performance structural materials (e.g., aerospace). Alternative precursors to reduce CF cost and dependence on fossil sources have been investigated over the years, including biomass-derived precursors such as rayon, lignin, glycerol, and lignocellulosic sugars.

The purpose of this study is to provide a comprehensive overview of CF precursors from biomass and their market potential. We examine the potential CF production from these precursors, the state of technology and applications, and the production cost (when data are available). We discuss their advantages and limitations. We also discuss the physical properties of biomass-based CF, and we compare them to those of polyacrylonitrile (PAN)-based CF. We also discuss manufacturing and end-product considerations for bio-based CF, as well as considerations for plant siting and biomass feedstock logistics, feedstock competition, and risk mitigation strategies. The main contribution of this study is that it provides detailed technical and market information about each bio-based CF precursor in one document while other studies focus on one precursor at a time or a particular topic (e.g., processing). Thus, this publication allows for a comprehensive view of the CF potential from all biomass sources and serves as a reference for both novice and experienced professionals interested in CF production from alternative sources.

Our examination of the pathways, technology maturity, opportunities, and barriers for biomassbased CF in the United States leads to the following findings:

- At this time, no biomass-based CF has been developed with the necessary structural properties to be used in the major CF applications (e.g., aerospace, wind, and automotive).

- The physical properties (primarily tensile strength, as well as others) determine the proper application or utilization of the various types of CF that can be developed from biomass sources.

- Rayon-based CF has a limited market share. It is used primarily in insulating and ablative applications because the strength of this type of CF is lower than that required for structural applications.

- Lignin-based CF is currently in the research and development (R\&D) phase. Based on current experimental efforts, the modulus and strength of lignin-based CF are too low to meet structural applications requirements, and thus current research is focused on nonstructural applications such as insulation.

- Glycerol is inexpensive and widely available, but the production of acrylonitrile (ACN) via direct ammoxidation from this resource has been found to be uneconomical at this time; it is about $67 \%$ more expensive than propane-based ammoxidation. Other 
conversion pathways have been investigated, but their cost effectiveness is yet to be determined.

- CF from lignocellulosic sugars is targeting functionally equivalent material to PAN-based CF. This pathway, currently in the R\&D phase, offers a "drop-in" bio-ACN; thus, it may be more readily commercialized than direct conversion of lignin to $\mathrm{CF}$, which requires the development of new manufacturing operations and hence, a longer commercialization process. However, the development of CF from lignocellulosic sugars faces competition for resources from other industries such as power generation and transportation fuels production.

- In addition to techno-economic viability, biomass-based CF-while potentially desirable from sustainability and cost perspectives-will have many implications and hurdles that need to be considered for manufacturing, feedstock supply, and end products, including material certification, product warranties, competitiveness of products, raw materials, and plant locations.

Our findings are also summarized in Table ES-1. 
Table ES-1. Summary Table of Key Findings

\begin{tabular}{|c|c|c|c|c|c|}
\hline $\begin{array}{l}\text { Biomass- } \\
\text { based CF } \\
\text { Precursor }\end{array}$ & $\begin{array}{l}\text { Potential CF } \\
\text { Production } \\
\text { (tonnes/yr) }\end{array}$ & $\begin{array}{c}\text { Technology } \\
\text { Pathway }\end{array}$ & $\begin{array}{c}\text { CF } \\
\text { Production } \\
\text { Cost }\end{array}$ & $\begin{array}{l}\text { Development } \\
\text { Stage }\end{array}$ & $\begin{array}{c}\text { Key } \\
\text { Commercialization } \\
\text { Challenges }\end{array}$ \\
\hline Rayon & $\begin{array}{l}\text { Data not available } \\
\text { (rayon is derived } \\
\text { from cellulose, an } \\
\text { abundant } \\
\text { feedstock) }\end{array}$ & Spinning & $\begin{array}{l}\text { Higher } \\
\text { production } \\
\text { cost than PAN- } \\
\text { based CF }\end{array}$ & $\begin{array}{l}\text { Commercial } \\
\text { (limited) }\end{array}$ & $\begin{array}{l}\text { Low tensile } \\
\text { strength, higher } \\
\text { production cost }\end{array}$ \\
\hline Lignin & 147,500 & Spinning & $\begin{array}{l}\text { \$4-\$6/lb. } \\
\text { (estimated for } \\
\text { commercial- } \\
\text { scale } \\
\text { production) }\end{array}$ & Bench scale & $\begin{array}{l}\text { Low tensile } \\
\text { strength, } \\
\text { manufacturing } \\
\text { limitations, } \\
\text { unproven scale of } \\
\text { commercial } \\
\text { operation }\end{array}$ \\
\hline Glycerol & $\begin{array}{l}\text { Data not available } \\
\text { (about } 575,000 \\
\text { tonnes of glycerol } \\
\text { produced in the } \\
\text { United States in } \\
2015 \text { ) }\end{array}$ & $\begin{array}{l}\text { Direct and } \\
\text { indirect } \\
\text { synthesis }\end{array}$ & $\begin{array}{l}\text { Likely pathway } \\
\text { (direct glycerol } \\
\text { to ACN) about } \\
67 \% \text { more } \\
\text { expensive than } \\
\text { petroleum- } \\
\text { derived PAN }\end{array}$ & Bench scale & $\begin{array}{l}\text { Limited research } \\
\text { (Europe), } \\
\text { higher production } \\
\text { cost (due to } \\
\text { purification needs in } \\
\text { ammoxidation } \\
\text { process) }\end{array}$ \\
\hline $\begin{array}{l}\text { Lignocellulosic } \\
\text { sugars }\end{array}$ & $\begin{array}{l}15,000,000 \\
\text { (from U.S. crop } \\
\text { residues) }\end{array}$ & $\begin{array}{l}\text { Catalytic } \\
\text { conversion, } \\
\text { biochemical } \\
\text { pathways }\end{array}$ & $\begin{array}{l}\text { Target cost of } \\
\text { ACN at } \\
\$ 1.00 / \mathrm{lb} \text {. (the } \\
\text { current cost of } \\
\text { petroleum- } \\
\text { derived } A C N \text { ) } \\
\text { or less, which } \\
\text { equals to CF } \\
\text { of about } \\
\$ 5.00 / / \mathrm{lb} \text {. by } \\
2020 \text {. }\end{array}$ & $R \& D$ & $\begin{array}{l}\text { Limited research, } \\
\text { feedstock } \\
\text { competition }\end{array}$ \\
\hline
\end{tabular}




\section{Table of Contents}

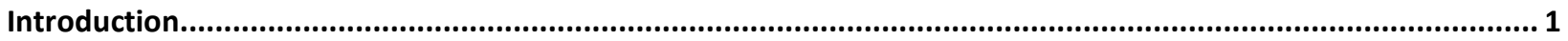

Carbon Fiber from Biomass Sources..................................................................................................

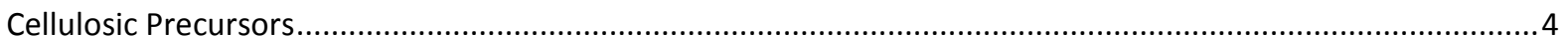

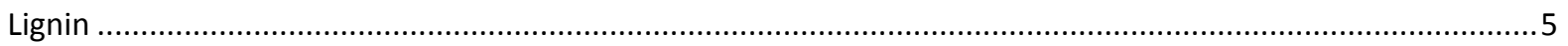

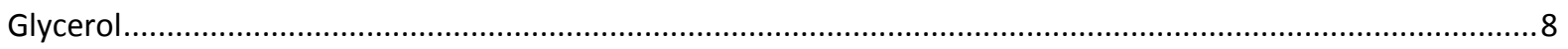

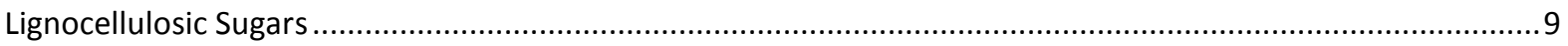

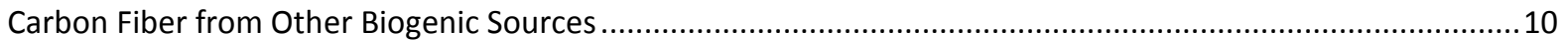

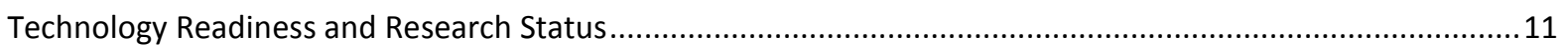

Supply Chain and Competitiveness Considerations......................................................................... 12

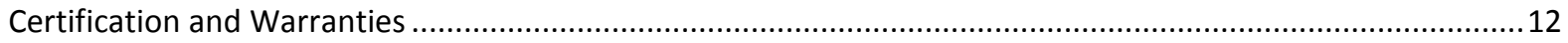

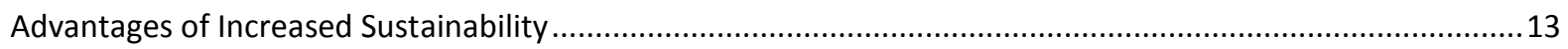

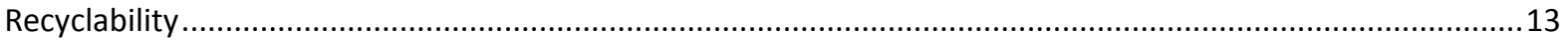

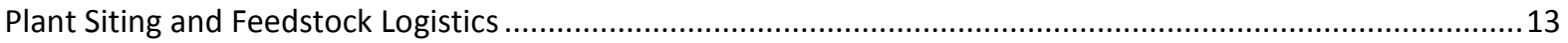

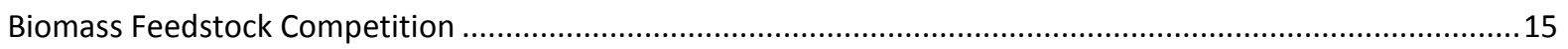

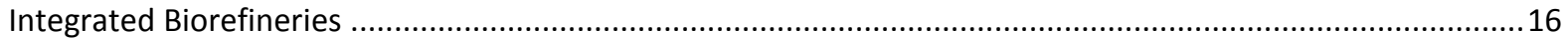

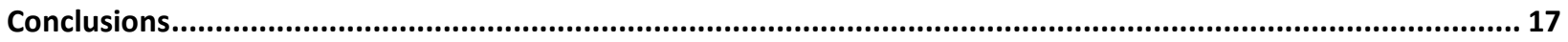

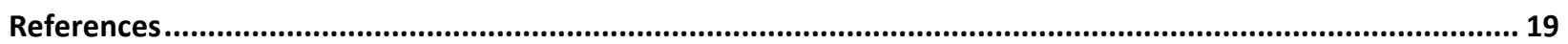

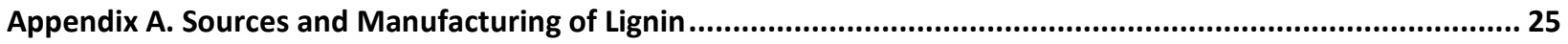

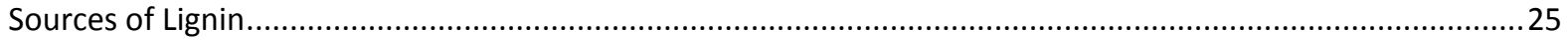

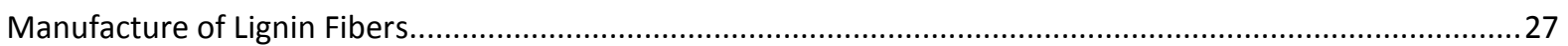




\section{List of Figures}

Figure 1. Global carbon fiber manufacturing facilities........................................................................

Figure 2. Carbon fiber manufacturing cost breakdown ............................................................................

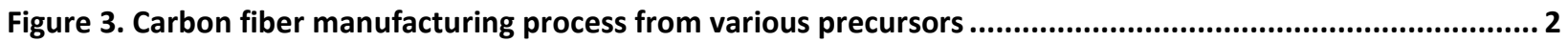

Figure 4. Carbon fiber properties from various precursors (in gray/black) compared to industry requirements

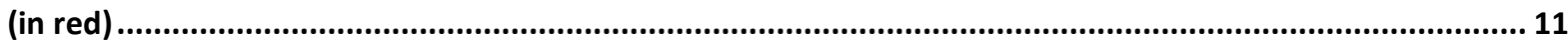

Figure 5. Carbon fiber manufacturing facilities and biomass resources in the United States.............................. 14

Figure 6. Integrated biorefineries and carbon fiber manufacturing facilities in the United States....................... 16

\section{List of Tables}

Table 1. Lignin Production, Purity, Carbon Fiber Suitability, and Potential Carbon Fiber Production .................... 6

Table 2. Lignin-Based Carbon Fiber Cost Savings Estimate Compared to Conventional PAN-based Carbon Fiber... 7

Table 3. Summary Table of Key Findings ................................................................................................... 18 


\section{Introduction}

Carbon fiber (CF), known also as graphite fiber, is a lightweight, strong, and flexible material used in both structural (load-bearing) and non-structural applications (e.g., thermal insulation). The most common CF precursor-the starting material used to make CF-is polyacrylonitrile (PAN), and it accounts for about $90 \%$ of CF production today. Acrylonitrile (ACN) is a global commodity that is used to produce PAN. About $55 \%$ of ACN manufacturing is in Asia, $15 \%$ in North America, and 10\% in Western Europe (Yang Qin 2015). Other precursors in use are rayon (regenerated cellulose), pitch (derived from petroleum or coal tar), and more recently, polyolefins (e.g., polyethylene and polypropylene). A map of CF manufacturing facilities is shown in Figure 1. Key manufacturing locations include the United States, Western Europe, China, and Japan.

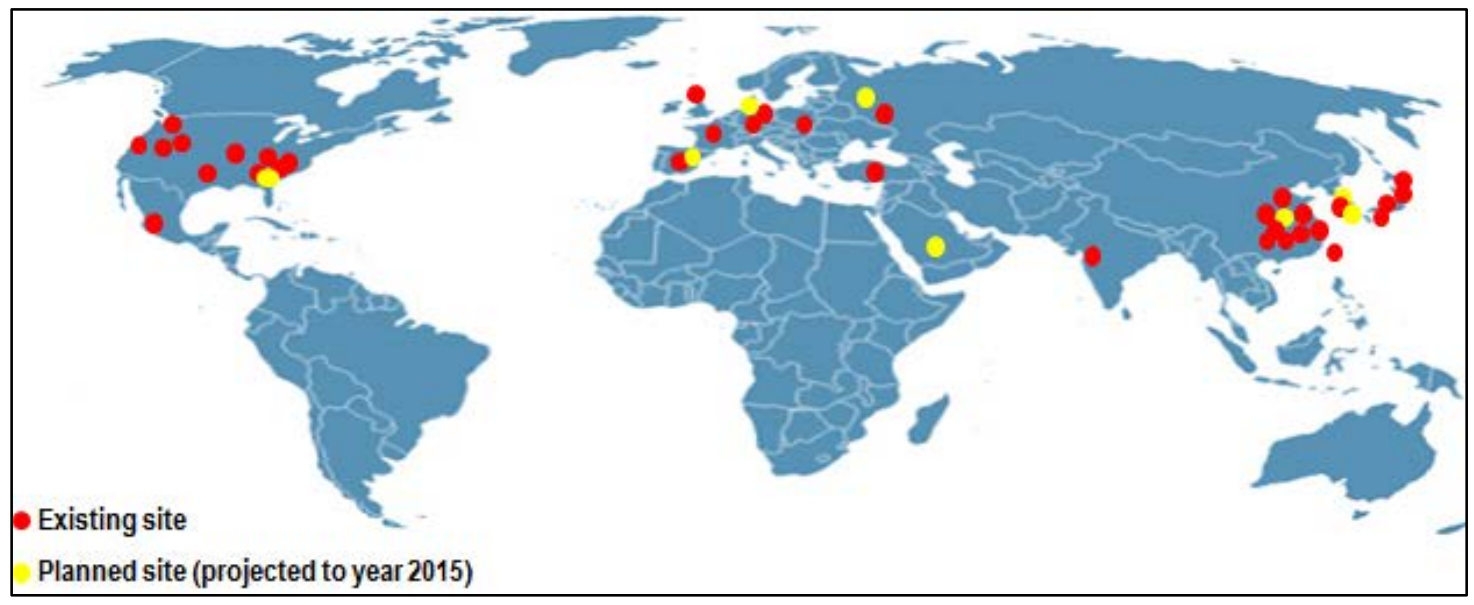

Source: Das et al. 2016

Figure 1. Global carbon fiber manufacturing facilities

Precursors, namely PAN, account for about $51 \%$ of the manufacturing cost of CF, and their high price is one of the barriers to their widespread use (Warren 2014; RMI 2015; DOE 2013).

Figure 2 shows a simplified CF manufacturing cost breakdown.

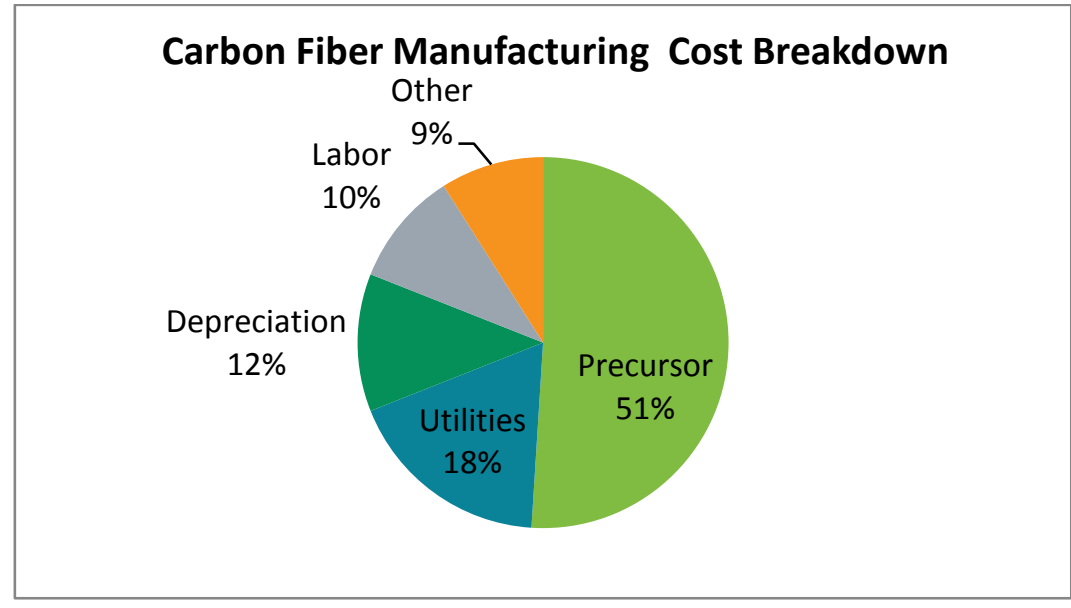

Source: RMI 2015

Figure 2. Carbon fiber manufacturing cost breakdown 
The current methods for manufacturing CF are slow and energy-intensive, and they thus contribute to the high cost of CF production. The high cost of precursors and manufacturing keep CF a niche market with applications limited to high-performance structural materials (e.g., aerospace). Advanced manufacturing technologies that use less energy are under exploration (e.g., microwave or plasma) (Brosius 2014). In addition, alternative precursors to reduce CF cost and dependence on fossil feedstock have been investigated over the years. These include biomass-derived precursors such as lignin, glycerol, and lignocellulosic sugars. Research on other fossil-based but lower-cost alternative precursors such as textile PAN and polyolefin is also ongoing, but this analysis is focused on biomass-based precursors. Although the preparation of each precursor (derived from either fossil sources or biomass) is different, they all follow similar processing steps for CF production, as illustrated in Figure 3.

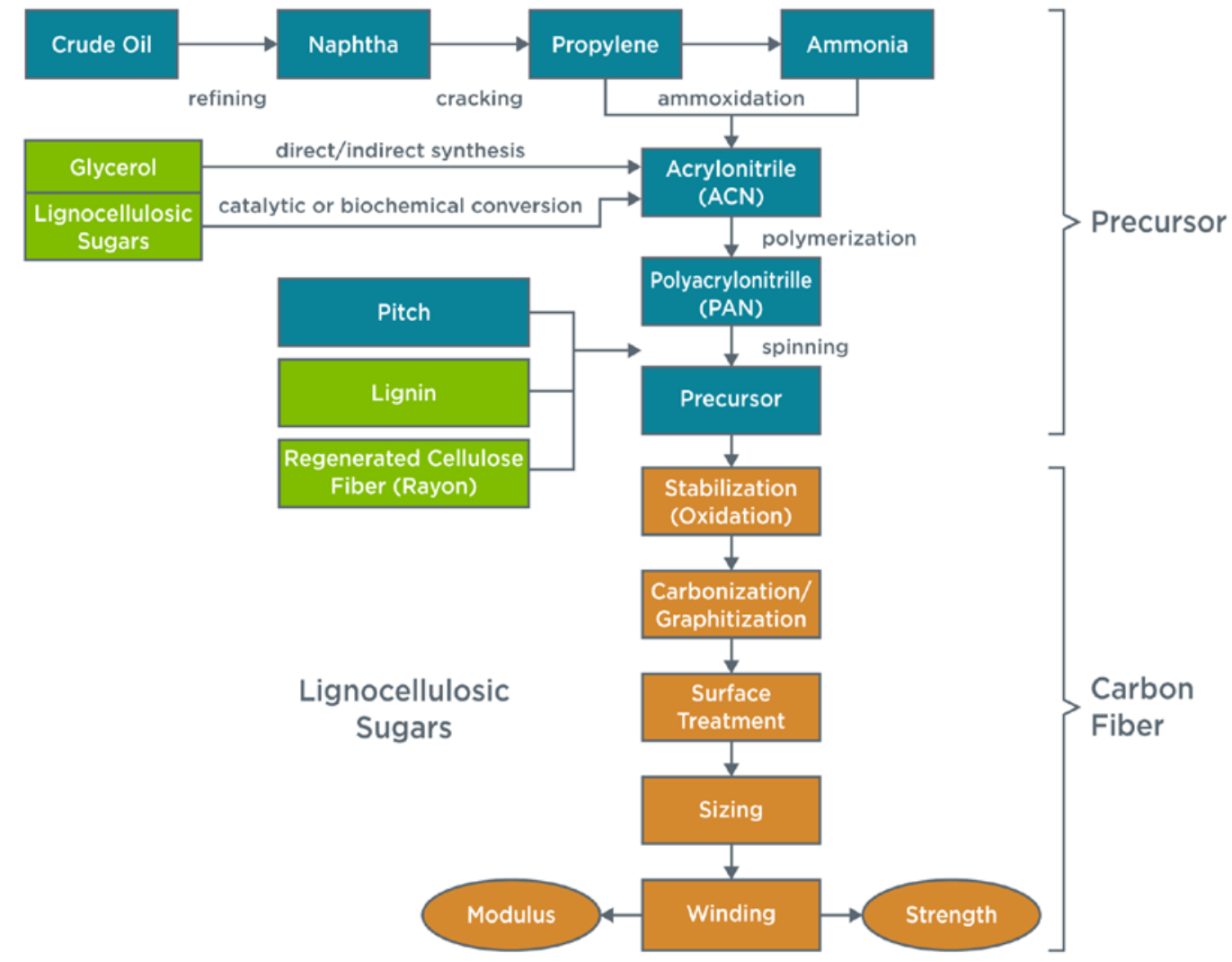

Figure 3. Carbon fiber manufacturing process from various precursors

The purpose of this study is to provide a comprehensive overview of the CF precursors from biomass and their market potential. Biomass-based precursors have been studied by national laboratories, universities, and others because they have the potential to substantially lower precursor costs for CF manufacturing. They also have the potential to lower other cost categories, including utility or capital equipment costs; however, this analysis is focused primarily on precursors. We examine the potential CF production from these precursors, the state of technology and applications, and production cost (when data are available) and we discuss their advantages and limitations. We also provide a discussion on the physical properties of biomass-based CF and compare them to those of PAN-based CF, manufacturing, and end-product considerations for bio-based CF, as well as considerations for plant siting and biomass feedstock logistics, feedstock competition, and risk mitigation strategies. The main 
contribution of this study is that it is the first to provide detailed technical and market information about each bio-based CF precursor in one document while other studies focus on one precursor at a time and/or a particular topic (e.g., processing). This allows for a comprehensive view of the CF potential from all biomass sources and serves as a valuable reference for both novice and experienced professionals interested in CF production from alternative sources. 


\section{Carbon Fiber from Biomass Sources}

\section{Cellulosic Precursors}

Cellulosic fibers are well-established precursors for CF production; the first CF introduced to the market in the 1960s was produced from rayon, which is made from natural, cellulose-based material (e.g., wood pulp, cotton linters, leaves, and the inner pith of bamboo plants) that is chemically processed to produce semi-synthetic fibers (ACS 2003). Types of rayon include viscose, modal, and lyocell (commonly sold under the brand name TENCEL made by Lenzing Group, Austria); each is produced via different process and characterized by different properties.

Today, PAN-based CF has replaced rayon-based CF in most applications because it is superior in several respects, especially tensile strength (ACS 2003). Also, despite having a lower raw material cost, a low char yield (20\%-25\%) after carbonization results in a higher overall cost of rayon-based CF (Walsh 2001). Walsh (2001) suggests that these properties can be improved by stress graphitization at high temperatures, but this increases cost further, making the fiber even less desirable. While CF from rayon is not used in structural applications, it is still used in the rocket and missile industry for ablative applications, such as reentry vehicle nosetips, heat shields, and solid rocket motor (SRM) nozzles and exit cones (Traceski 1999). Rayon-based CF can withstand the high temperature and erosive gases of SRM operation and the high temperatures generated by aerodynamic heating on missile reentry systems (Traceski 1999).

Rayon-based CF has limited commercial production (about $1 \%-2 \%$ of the total CF production) due to low demand. The RUE-SPA-Khimvolokno in Belarus is the main rayon-based CF producer in the world (Dumanli and Windle 2012). Rayon fibers are not produced in the United States, but they are of interest to the U.S. Department of Defense due to their superior ablation performance described above and as a domestically produced material (Bhat et al. 2013). Ongoing research on CF from rayon at the University of Tennessee uses experimental rayon fibers from Advanced Cerametrics in Lambertville, New Jersey as well as commercial rayon fibers from Lenzing Group (Bhat et al. 2013).

Rayon-based CF is produced similarly to PAN-based CF, and the production consists of three main stages: stabilization of the precursor (low temperature oxidation), carbonization (longitudinal orientation and development of the crystalline ordering), and graphitization (optional for high modulus). Natural fibers such as cotton and ramie have not been favored for CF production because of their discontinuous filament structure and low degree of orientation, as well as impurities associated with their complex structure (Dumanli and Windle 2012). However, advanced processing technologies and a search for renewable sources may open new opportunities for natural fibers as alternative CF precursors in the future. 


\section{Lignin}

Lignin is the second-most abundant natural polymer (after cellulose) that provides structural support in plants and algae. It is a byproduct of the pulp and paper industry as well as cellulosic ethanol production, and it is often burned onsite to provide steam for heat and power generation. Other than being an inexpensive fuel, lignin is considered a promising precursor for $\mathrm{CF}$ and other carbonaceous materials that offer a higher-value market for this product.

Sources of lignin include the four commercial and non-commercial processes briefly described below. Additional information on lignin sources and manufacturing is provided in Appendix A.

1. Sulfite pulping is a chemical pulping process that has largely been displaced by alkaline (kraft) pulping. Lignosulfonates, or sulfonated lignin, are isolated from spent sulfite-pulping liquids (red or brown liquor). Lignosulfonates are water-soluble and the most important commercial source of lignin. They are used as dispersants, binders, complexing agents, and emulsifying agents (Lignoworks 2015). Today, Borregaard LignoTech, a Borregaard business unit, is the world's largest producer of lignosulfonates (Dahlquist 2013).

2. Kraft (sulfate) pulping is the most widely used chemical pulping process in the world. It employs a combination of high temperature and alkaline chemicals to separate lignin from the cellulose fibers needed for papermaking. The extracted liquid, known as black liquor, contains lignin, hemicellulose, inorganic compounds, and spent cooking chemicals. Lignin is recovered from black liquor through several processes (see Appendix A). Several companies (e.g., MeadWestvaco and Metso) isolate kraft lignin for sale as an industrial product. This lignin is used in niche applications such as dispersants for dyes and pesticides (Lignoworks 2015). Other applications include the use of lignin as a renewable replacement for certain glue components used in the manufacture of plywood and engineered wood products such as laminated veneer lumber and oriented strand board (Tuck and Hunter 2015).

3. Organosolv pulping, also called solvent pulping, is a process that uses organic solvents (e.g., methanol, ethanol, butanol, and acetic acid) as delignification agents. Solvent pulping offers a potential advantage to traditional kraft pulping in that it can produce sulfur-free lignin that is extracted at a much faster rate than is possible with the kraft process (IETD, n.d.). However, the high cost of solvents can be cost prohibitive (IETD, n.d.). Several solvent pulping technologies have been developed, but no commercial operations are using them. The Organosolv process has been considered as a pretreatment step in cellulosic ethanol production. Cellulosic ethanol is now being produced commercially in the United States, Europe, and Brazil. See Appendix A for more information.

4. Hydrotropic pulping is a process that uses concentrated aqueous solutions of hydrotropic agents (salts that, at high concentration, considerably improve the aqueous solubility of poorly soluble substances) at elevated temperatures (Gabov, Fardim, and da Silva Júnior 2014). Unlike the lignin recovered through sulfite or kraft pulping, which uses contaminating inorganic chemicals, the lignin recovered through precipitation by hydrotropic pulping is relatively pure and is suitable for conversion to other chemical products (U.S. Congress 1989). However, the hydrotropic process is unsuitable for softwood (e.g., pine, fir, and spruce), which is the primary reason it has received limited attention by the industry (U.S. Congress 1989). Increasing demand for bio-based products may bring this process back into consideration, especially given recent efforts in growing woody crops such as poplar and willow for energy. See Appendix A for more information. 
Potential CF production from lignin is estimated at about 148,000 tonnes per year (Table 1 ). The global CF demand was estimated at about 65,000 tonnes in 2015 , and it was projected to increase to 170,000 tonnes by 2025 (Black and Sloan 2015). Therefore, the estimated ligninbased CF production potential could meet a substantial portion of the projected 2025 demand; however, as discussed in detail below, the lignin-based CF does not offer the same quality or strength as petroleum-based CF for structural applications. The estimated CF quantity comes from commercial kraft and Organosolv processes because they produce relatively pure (i.e., low ash content, no sulfur) lignin, which is important for CF manufacturing. Hydrotropic lignin has been demonstrated to be of very high quality and thus suitable for CF production as well, but there is no commercial production today. The high sulfur content of lignosulfonates prevents the use of lignin in CF production, as a fuel additive, and in other applications. The low-quality kraft lignin (not to be confused with the high-quality commercial kraft lignin) production is estimated at about 50 million tonnes annually, but much of this amount is not isolated and is burned as a fuel onsite (Higson 2011; Smolarski 2012). This is a relatively low-value use of lignin.

Assuming a heating value of about 8,000 British thermal units (Btu) per pound of lignin and a market value of $\$ 3-\$ 10$ per million Btu, the market value equates to about $\$ 0.02$ to $\$ 0.08$ per pound of lignin. Using lignin for CF production would provide much higher added value, for comparison purposes the market value of petroleum derived ACN is approximately $\$ 1$ per pound and CF is $\$ 5-\$ 10$ per pound for industrial grades. As interest in alternative uses of lignin grows and lignin-recovery processes further commercialize, more high-purity lignin is expected to be available on the market, and the potential for CF production from this precursor will thus be higher.

Table 1. Lignin Production, Purity, Carbon Fiber Suitability, and Potential Carbon Fiber Production

\begin{tabular}{|c|c|c|c|c|}
\hline Lignin Type & $\begin{array}{l}\text { World Annual } \\
\text { Production } \\
\text { (tonnes/yr) }\end{array}$ & Lignin Purity & $\begin{array}{c}\text { Suitable for } \\
\text { CF }\end{array}$ & $\begin{array}{l}\text { Potential CF Production } \\
\text { (tonnes/yr) }\end{array}$ \\
\hline Kraft & $50,000,000$ & Low & No & $\mathrm{n} / \mathrm{a}$ \\
\hline Commercial kraft ${ }^{1}$ & 114,000 & High & Yes & 57,000 \\
\hline Lignosulfonates & $1,000,000$ & Low-medium & No & $\mathrm{n} / \mathrm{a}$ \\
\hline Organosolv $^{2}$ & 1000 & High & Yes & 500 \\
\hline Ethanol biorefineries ${ }^{3}$ & 180,000 & High & Yes & 90,000 \\
\hline Hydrotropic & - & High & Yes & - \\
\hline Total & $51,295,000$ & & & 147,500 \\
\hline
\end{tabular}

"-" = information not available; "n/a" = not applicable Sources: Smolarski 2012; Lake and Scouten 2014; Wertz and Bédué 2013; Valmet 2015

Conversion of lignin to $\mathrm{CF}$ assumes that about two tonnes of lignin are needed to produce one tonne of CF via melt spinning (Axegard, Tomani, and Hansson 2013).

${ }^{1}$ Commercial kraft lignin (high purity) is produced by MeadWestvaco and Domtar in the United States (about 60,000 tonnes per year), Stora Enso Sunila mill in Finland (about 50,000 tonnes), and Metso Corporation at a demonstration plant in Sweden (about 4,000 tonnes per year) (Lake and Scouten 2014; Wertz and Bédué 2013; Valmet 2015).

2 Organosolv lignin is mostly produced in pilot plants by CIMV (France) and Lignol (Canada).

${ }^{3}$ About $0.3 \%$ of total potential is produced today (Lake and Scouten 2014). 
Lignin is the most-studied biogenic CF precursor, with more than 50 years of research and significant investments. Lignin-based CF offers a potentially compelling manufacturing cost advantage over current technologies, costs estimates at commercial scale are about $\$ 4 / \mathrm{lb}-$ $\$ 6 / \mathrm{lb}$ versus $\$ 10 / \mathrm{lb}$ for petroleum-based CF (in 2010 dollars) (ORNL 2011; RMI 2015). Conventional PAN precursor costs are $\$ 4 / \mathrm{lb}-\$ 5 / \mathrm{lb}$, and lignin costs are $\$ 0.25 / \mathrm{lb}-\$ 0.70 / \mathrm{lb}$ (Warren 2011; GrafTech 2015). This large reduction in precursor costs accounts for the majority of potential manufacturing cost savings. However, potential savings in other areas of the process have also been investigated. A cost comparison is presented in Table 2 that illustrates other potential savings in the production and manufacturing process (Baker 2010).

Table 2. Lignin-Based Carbon Fiber Cost Savings Estimate Compared to Conventional PAN-based Carbon Fiber ${ }^{1}$

\begin{tabular}{|l|ll|ll|}
\hline Process Cost Category & \multicolumn{2}{|l|}{\begin{tabular}{l}
\multicolumn{2}{l|}{ PAN-Based CF Cost } \\
Estimate (\$9.88/lb)
\end{tabular}} & \multicolumn{2}{l|}{$\begin{array}{l}\text { Lignin-Based CF Cost } \\
\text { Estimate (\$3.71/lb) }\end{array}$} \\
\hline Precursors & $\$$ & 5.04 & $\$$ & 0.50 \\
\hline Stabilization and oxidation & $\$$ & 1.54 & $\$$ & 0.99 \\
\hline Carbonization and graphitization & $\$$ & 2.32 & $\$$ & 1.48 \\
\hline Surface treatment & $\$$ & 0.37 & $\$$ & 0.33 \\
\hline Spooling and packaging & $\$$ & 0.61 & $\$$ & 0.41 \\
\hline
\end{tabular}

Source: Baker 2010, in 2010 dollars

CF production costs are difficult to generalize and the table above simply presents one highlevel example; costs can vary significantly by many other factors, such as scale of manufacturing, facility location, energy costs, and fiber quality. Das et al. (2016) presents a detailed analysis of CF manufacturing costs for 24-k tow CF for pressure vessels with an average cost of approximately $\$ 10.30$ per pound. This is an example of a specific fiber whose cost could also potentially be reduced with a reduction in precursor or other costs if lignin could be used to make this fiber.

The lignin-to-CF pathway is not commercially available due to performance issues and manufacturing limitations. Various entities have been involved in lignin-based CF research, but most notable in the past 10 years are the efforts led by the Oak Ridge National Laboratory (ORNL) and Innventia, which both produce CF for test purposes. These entities work toward addressing commercialization challenges associated with manufacturing of lignin-based CF such as "melt processability (especially for softwood lignins); long heat treatment time (especially for hardwood lignins); variability in the feedstock; need for purification and fractionation; inability to reach targets for strength and stiffness of finished fiber; and unproven scale of operation" (DOE 2013, page 3). These challenges are due to lignin's heterogeneous molecular weight, functionality, and thermal properties that vary with the source and isolation process of lignin (Chatterjee and Saito 2015).

\footnotetext{
${ }^{1}$ This cost comparison is from 2010 and a more recent comparison was unavailable. PAN-based CF manufacturing costs have declined slightly since then and are now approximately $\$ 8$ per lb for the baseline scenario.
} 


\section{Glycerol}

Glycerol (known also as glycerine or glycerin) is used in cosmetic, pharmaceutical, and food products, but it also has potential as a renewable source for production of chemicals. It can be used to produce ACN which can then be polymerized and spun into PAN and subsequently converted to CF. Two conversion processes of glycerol to ACN are described in the literature:

- Direct synthesis in gas or liquid phase, employing ammoxidation ${ }^{2}$ in the former and microwave heating in the latter phase (Patent US20100048850 A1; Casilda, GuerreroPerez, and Banares 2009)

- Indirect synthesis via acrolein-glycerol is dehydrated to form acrolein, which is followed by ammoxidation of acrolein to $\mathrm{ACN}$-or allyl alcohol; using iron oxide as a catalyst, glycerol can be converted to allyl alcohol through a dehydration and consecutive hydrogen transfer, followed by ammoxidation of allyl alcohol to ACN (Liu et al. 2010; Guillon et al. 2013) as intermediates.

In the past, glycerol was obtained primarily from petroleum via synthetic processes. However, over time, glycerol from plant and animal sources became readily available as a byproduct of several industrial processes such as biodiesel production, hydrolysis of fatty acids, and soap making. Today, biodiesel production is the largest source of glycerol, accounting for about $63 \%$ of the market in 2013 (Grand View Research 2014). Global glycerol demand was 2.2 million tonnes in 2013, and it is expected to reach 3.5 million tonnes by 2020 (Grand View Research 2014). This demand is driven primarily by the food \& beverage industry given the improving lifestyle in emerging economies and leading to increased consumption of processed and packed foods (Grand View Research 2014). Approximately 575,000 tonnes of glycerol were produced in the United States in $2015^{3}$. Increased biodiesel production in recent years has resulted in an oversupply of glycerol for U.S. markets leading to low prices for crude glycerol of around $\$ 0.10 / \mathrm{lb}$ with higher prices for upgraded or refined glycerol (Schwab et al. 2016).

Despite resource abundance, there has been limited research of glycerol-to-ACN pathways. A study by Guerrero-Perez and Banares (2015) indicates that the ACN production from glycerol via direct ammoxidation is uneconomical at this time. The authors estimate that glycerol ammoxidation is about $67 \%$ more expensive than propane ammoxidation. While crude glycerol is relatively inexpensive, purification is needed for the ammoxidation process, which contributes to the higher raw material and investment costs (impurities include alcohol, water, and other organic compounds). Moreover, Guerrero-Perez and Banares (2015) indicate that the petrochemical route is more advantageous, not only in terms of raw material cost but also in terms of energy efficiency. The energy requirement to heat propane from $20^{\circ} \mathrm{C}$ to $480^{\circ} \mathrm{C}$ is 782 megajoule (MJ) per tonne while the energy requirement to evaporate and heat glycerol from $20^{\circ} \mathrm{C}$ to $400^{\circ} \mathrm{C}$ is $1,575 \mathrm{MJ} /$ tonne. No economic analyses were found for other glycerol-to-

\footnotetext{
2 The glycerol is reacted with ammonia and oxygen in the presence of an acid catalyst.

${ }^{3}$ Each gallon of biodiesel produced results in about one pound of glycerol. Based on this ratio, EIA's estimated total U.S. production of 1.268 billion gallons of biodiesel in 2015 would yield about 634,000 tons of glycerol (http://www.eia.gov/biofuels/biodiesel/production/table1.pdf).
} 
ACN pathways, although Casilda, Guerrero-Perez, and Banares (2009) indicate that the microwave-assisted process may be cost-effective.

\section{Lignocellulosic Sugars}

Another pathway for production of ACN involves using biomass-derived sugars (e.g., glucose, fructose, and xylose) derived from the cellulose and hemicellulose fractions of biomass.

Laboratory tests have shown that this pathway can lead to a direct replacement of conventional ACN with comparable mechanical properties (DOE 2013). Considering this opportunity, the U.S. Department of Energy awarded two projects in 2014 that aim to advance the production of low-cost, high-performance CF from renewable, non-food-based biomass feedstocks (DOE 2014a).

- Southern Research Institute (SRI) of Birmingham, Alabama, will employ a multi-step catalytic process for conversion of sugars from non-food biomass to ACN.

- National Renewable Energy Laboratory (NREL) of Golden, Colorado, will investigate and optimize multiple biochemical pathways to ACN.

The goal of these research activities is to enable technologies that can produce biomass-based $\mathrm{ACN}$ at a modeled cost of $\$ 1.00 / \mathrm{lb}$ (the current cost of petroleum-derived ACN) or less, thereby making the overall manufacturing of CF less than or equal to $\$ 5.00 / \mathrm{lb}$ by 2020 suitable for vehicle structural components (Green Car Congress 2014).

The theoretical CF production potential from U.S. crop residues is estimated at about 15 million tonnes per year, according to Mary Biddy of NREL (pers. comm., February 2016), which is substantially more than the projected CF demand of 170,000 tonnes in 2025 (Black and Sloan 2015). This production estimate considers a biochemical conversion pathway of harvesting residues from major crops (corn, wheat, grain sorghum, rice, barley, oats, sugarcane, and cotton); it amounts to about 125 million tonnes per year (Schwab et al. 2016). Additional CF for future market growth could be produced if other lignocellulosic sources were considered in addition to crop residues such as dedicated energy crops (e.g., switchgrass, miscanthus, and short-rotation woody crops) and forest residues. 


\section{Carbon Fiber from Other Biogenic Sources}

Another biogenic source that has been researched for ACN production is glutamic acid, which is available from a wide range of waste streams such as the dried distiller's grains and solubles of ethanol production from corn and wheat. Le Notre et al. (2011) report that the routes to convert glutamic acid to ACN are technically and economically feasible. The transformation involves a two-step procedure involving an oxidative decarboxylation in water to 3cyanopropanoic acid followed by a decarbonylation-elimination reaction using a palladium catalyst (Le Notre et al. 2011). Other studies to confirm these findings have not been published at this time.

Genetic modification of biomass has been mentioned as another route to CF production. This pathway involves (1) engineering plants to synthesize lignin or other natural polymers that could be converted to PAN-like materials as well as (2) using $\mathrm{CO}_{2}$ or carbon nanotubes via yetto-be-developed technologies (DOE 2013). Additionally, chicken feathers have been investigated as a material for CF production by researchers at the University of Delaware. They developed chicken feather fibers with low modulus and low/medium strength; they have goals to increase these parameters, but their research in this area has been limited in recent years (Miller and Wool 2006; Miller and Wool 2007; Zhan and Wool 2011). 


\section{Technology Readiness and Research Status}

At this time, no biomass-based CF has been developed with the necessary structural properties to be utilized in the major CF applications (e.g., aerospace, wind, and automotive). As illustrated in Figure 4, the CF materials from the two biogenic precursors in use (rayon) and in study (lignin) do not meet the mechanical properties required for structural applications; however, they are suitable for non-structural or functional applications (e.g., energy storage, filtration, and thermal management) with a very small share of the overall CF market. Research and testing is being funded to improve the properties of lignin-based CF and to demonstrate the technical and economic feasibility of CF from lignocellulosic sugars. Research on CF from rayon is limited at this time, led predominately by the U.S. Department of Defense. Research on CF from glycerol has also been limited, led primarily by universities in Europe. Additional technoeconomic analyses can identify the market viability of these biogenic CF pathways.

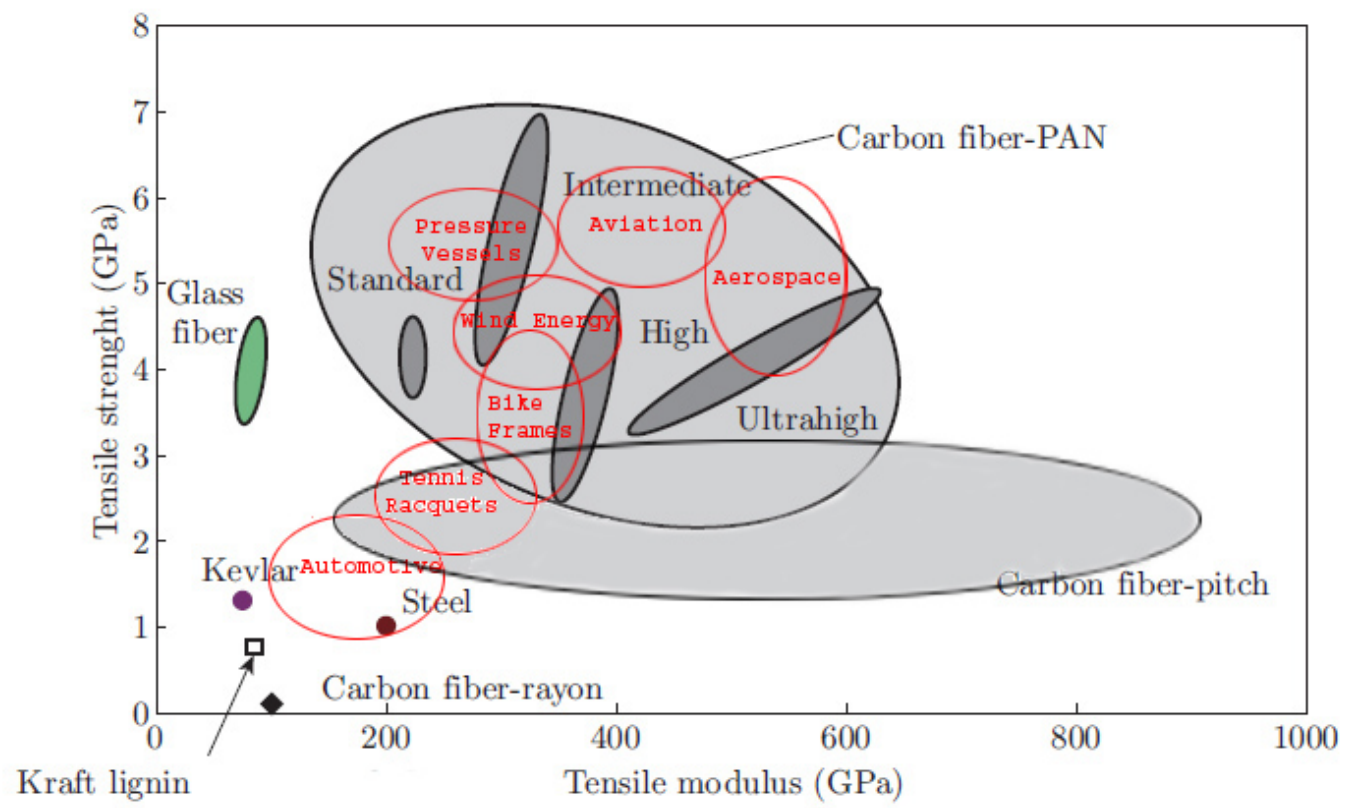

Sources: Lin et al. 2013; Downing 2013; Dumanli and Windle 2012

Figure 4. Carbon fiber properties from various precursors (in gray/black) compared to industry requirements (in red)

Most technologies discussed above (except CF production from rayon) are at relatively low technology readiness levels as they have only been demonstrated at the bench or pilot scale in a laboratory environment. Significant investments in scale-up evaluation, testing, and equipment development would likely be required to transition any of these technologies from their current state to a commercial facility. Scale-up and manufacturing consistency can be particularly challenging for biomass technologies because of the heterogeneity of feedstocks, which could add significant complexity to CF manufacturing steps such as melt spinning or stabilization. 


\section{Supply Chain and Competitiveness Considerations}

While changing the raw material for CF to a biomass source is potentially desirable from sustainability and cost perspectives, doing so would have implications that need to be considered for manufacturing, feedstock supply, and end products, including material certification, product warranties, competitiveness of products, raw material, and plant location.

\section{Certification and Warranties}

Structural applications of CF dominate the market in many key industries such as aerospace and wind. These industries typically have very stringent material requirements. If bio-derived ACN could be made that is chemically and physically identical to existing ACN sources, the current process for producing PAN and CF could be utilized. If the CF end product were identical in terms of material properties, it has the potential to compete and gain acceptance in the market after demonstrating that it met existing standards and tests such as those from the American Society of Mechanical Engineers and the American Society for Testing and Materials Standards. If end-product manufacturers and end-users would accept this biomass-derived CF as identical to previous products, it could be integrated into the supply chain with minimal difficulty after sufficient testing and demonstration.

However, if new and different certification processes were required for end products, this could be a significant barrier to adoption. The data and tests required for aerospace material qualification often require millions of dollars and multiple years (Brice 2011). These qualification requirements make adoption of new materials both time-consuming and expensive. For example, in a recent lecture, a Purdue University researcher stated, "It costs $\$ 100$ million per material to qualify composites to fly on a new airframe. Once certified, materials changes are economically impossible" (Vanderbilt 2015, paragraph 7). Therefore, adoption of biomass-based CF into the aerospace market is unlikely in the near term, as significant time and effort would need to be spent recertifying components. ${ }^{4}$ The time and effort would greatly outweigh the potential benefits of slightly less expensive new fiber. New designs could consider biomass-based CF, but adoption would likely be very limited until its mechanical properties and long-term performance were well established and the risk of any change had been reduced. Other industries with less stringent material certification requirements such as sporting goods or automobiles would likely be better early adopters of biomass-based CF than the aerospace industry.

Another related issue is with warranties from products made from CF, as a number of existing products made from CF such as automobiles and bicycles carry warranties. Companies offer these warranties because their customers demand them or they provide a business advantage. Any company with a strong warranty, such as BMW, which provides a 4-year warranty on CF interior components, would need to be convinced of the long-term performance characteristics of biomass-based CF.

\footnotetext{
${ }^{4} \mathrm{CF}$ is currently used extensively by the aircraft industry, including in aircraft such as the Boeing 787 Dreamliner, this statement simply refers to the likelihood of companies such as Boeing switching types of CF once certified.
} 


\section{Advantages of Increased Sustainability}

Utilizing CF from biomass may present a competitiveness advantage in some industries. For example, many existing sporting good products use CF to reduce weight and increase strength. A number of these manufacturers also highlight the sustainable attributes of the products they make. Some snowboards are marketed as containing sustainably harvested and certified wood cores with minimized environmental impacts. Many snowboards also contain CF for improved performance. For some companies, the ability to market sustainable CF made from biomass (not fossil sources) could have a favorable competitive advantage and be a differentiator, thus potentially making CF worth the risk contained in switching materials.

A number of retailers and manufacturers are trying to lower the environmental impact of the products they make or sell. For example, many retailers put pressure on their suppliers to lower their environmental footprint and their prices. If CF from biomass could provide a cost reduction and environmental benefit for a product such as a tennis racket, switching materials could likely be encouraged. In addition, many manufacturers, especially in Europe, are under increased pressure to reduce the footprint of the products they make; using a low-impact material such as biomass-based CF could be promoted by sustainability personnel, activists, or shareholders.

\section{Recyclability}

Several ongoing research projects have identified recyclability of CF at the end of its useful life as a known issue, but few current viable solutions have been presented. Starting in 2015 , the European Union end-of-life vehicle (ELV) directive ${ }^{5}$ requires that $85 \%$ of the materials used in each car by weight must be recyclable (Gardiner 2014). Metals and other automotive plastics are recyclable; however, generally, CF is not recyclable at present. If CF is to become a significant automotive component in Europe, it needs to be recyclable. The aerospace industry in Europe faces similar issues, and Airbus has set a target to recycle $95 \%$ of its CF-reinforced plastic by 2020-2025 (Lyons 2014). If biomass-based CF featured an improved path to recyclability, it could have a considerable supply chain advantage and may see increased adoption. However, if biomass-based CF was chemically identical to petroleum-based CF then it would face the same recycling challenges and likely not offer an advantage in this area. Recyclability of biomass-based CF has yet to be studied extensively and this is an area that requires further research to better understand the path and potential for recycling.

\section{Plant Siting and Feedstock Logistics}

CF manufacturing plants have been sited based on several factors such as proximity to customers or low-cost energy. Most of these existing facilities are located near biomass sources, which may present an opportunity for integrating these alternative sources into the CF manufacturing process (Figure 5). With only one or two exceptions, the CF manufacturing plants are in very close proximity not only to solid biomass resources (e.g., crop residues, forest residues, or both) but also to pulp and paper mills, which serve as a proxy for lignin production.

\footnotetext{
${ }^{5}$ Directive 2000/53/EC, http://ec.europa.eu/environment/waste/elv/.
} 


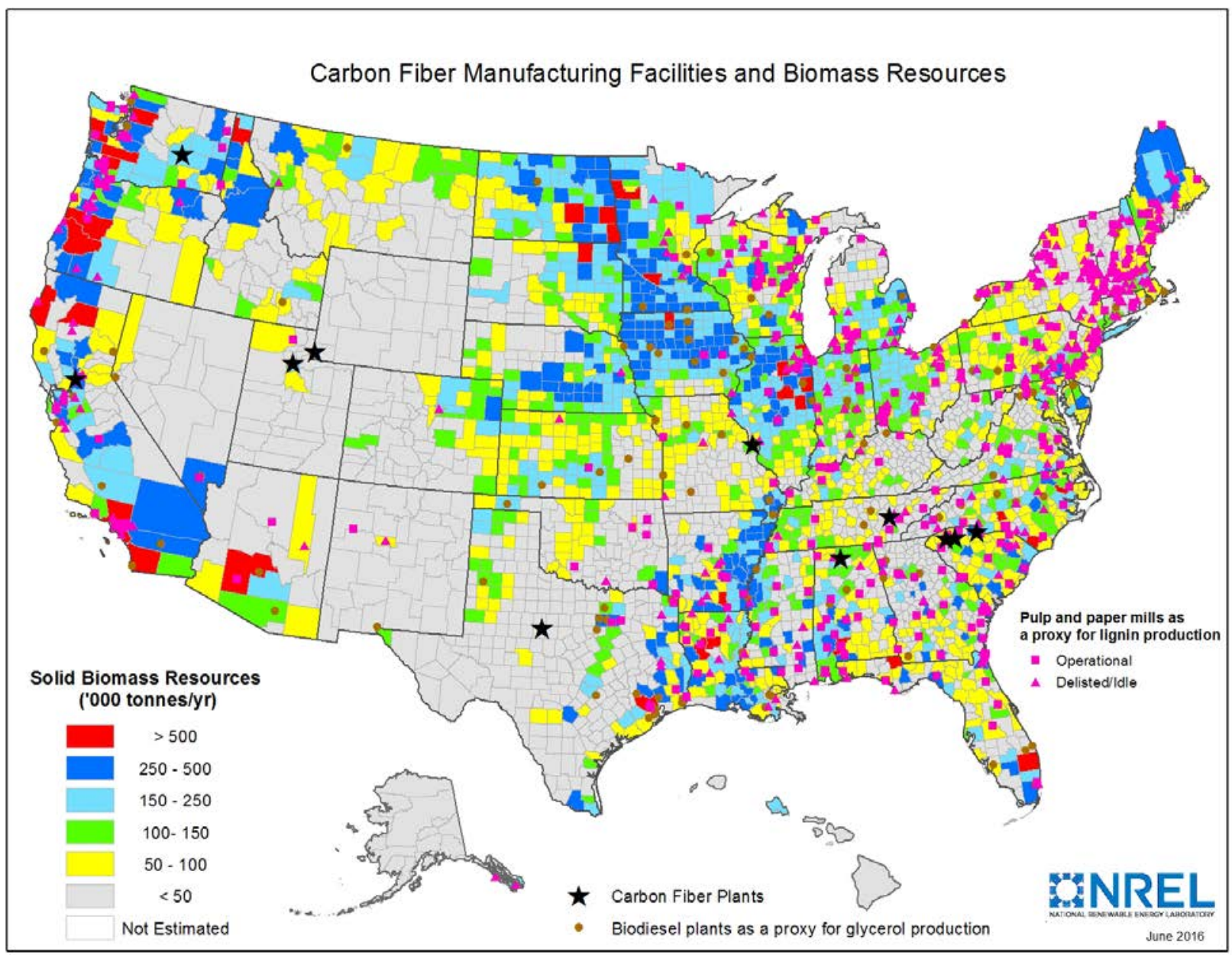

Figure 5. Carbon fiber manufacturing facilities and biomass resources in the United States

The logistics of packaging and shipping these raw materials must be properly accounted for and considered in the economic analysis of biomass-based CF. Precursors, namely PAN or ACN, are already shipped to the majority of CF manufacturing locations in the United States, often from other countries, so these facilities are currently importing material for manufacturing CF and could presumably switch to importing biomass or biomass derived precursors such as ACN or PAN. Typically, the costs of shipping the precursor to the manufacturing site are built into the precursor cost estimate as shown in the simplified CF manufacturing cost breakdown in Figure 2. Reducing these shipping costs by utilizing a local biomass feedstock could present a small competitive advantage. A study looking at manufacturing of CF in Iceland estimates precursor shipping costs from Europe or the United States at about $\$ 0.19 / \mathrm{lb}$ or about $2 \%$ of total manufacturing costs (Omnia 2012). As another example, the Mitsubishi Rayon CF Manufacturing Facility in Sacramento CA does not produce its precursor on site but imports it from Japan (Das et al. 2016). A local biomass feedstock for producing precursor has the potential to then save roughly $\$ 0.27 / \mathrm{lb}$ of CF for this facility or about $3 \%$ of production costs. ${ }^{6}$

\footnotetext{
${ }^{6}$ This assumes that (1) shipping costs for a container from Asia to California would be $\$ 4,500$ and would include shipping and import/export fees, (2) a shipping container can hold 35,000 pounds of precursor, (3) trucking would cost $\$ 1.70$ per mile (ATRI 2015) from Oakland to Sacramento and the trip would 100 miles, (4) two pounds of PAN precursor yields one pound of CF, and (5) production costs are approximately $\$ 8$ per pound.
} 
Shipping costs are of course highly dependent on the mode of transportation, and ocean container shipping, which is one of the most economical methods, was used predominantly in this estimate. Trucking costs in the United States were approximately $\$ 1.70$ per mile for a shipping container in 2015 (Torrey and Murray 2015). Shipment of precursor from Hexcel or Toray facilities in Decatur, Alabama to California by truck would cost about the same amount as ocean container shipping from Asia to California.

Transportation of a local biomass source to a CF manufacturing facility also has a cost. For example, an average transportation cost for corn stover is about $\$ 12.40$ per dry ton within a $50-$ mile radius. ${ }^{7}$ This would equate to a total shipping cost of about $\$ 0.01 / \mathrm{lb}$ of CF from this facility or about a $\$ 0.26 /$ lb savings.

Some biomass resources (e.g. lignocellulosic biomass such as crop residues) have costs associated with purchasing them up to $\$ 100 /$ dry ton and in some cases more (DOE 2016). Even at the high end of costs this is only a few cents per pound compared with the current cost of ACN which is approximately a dollar per pound.

The decision on where to locate a manufacturing facility for biomass-based CF will depend on project specifics such as biomass feedstock availability and cost, existing company plant locations, energy costs, and other considerations. Capital costs for a new CF manufacturing facility are very high. For example, Toray is investing approximately \$1 billion USD to build a new facility in South Carolina that will create 500 new jobs and produce 2,000 metric tons per year of CF along with precursor and prepreg. ${ }^{8}$

\section{Biomass Feedstock Competition}

The biomass resources that could be used to produce CF have other current or potential uses and applications. For lignocellulosic material, those include the production of power/heat, transportation fuels, and other chemicals. As mentioned earlier, glycerol is currently used predominantly in personal care and pharmaceuticals but food and beverage is expected to be the fastest growing application segment between now and 2020, owing to improving lifestyle in emerging economies leading to increased consumption of processed and packed foods (Grand View Research 2014). There is ongoing research on the production of other value-added materials from lignin such as aromatic chemicals, plastics, and liquid fuels.

A key consideration for the long-term viability of the industry will be the ability to secure a supply of raw material at an acceptable price. Competition from other industries for the biomass adds potential feedstock supply risk. For example, a report from the Pacific Northwest National Laboratory lists CF as just one of 43 potential products derived from lignin (Holladay 2007). CF is a high-value product, and it would likely compete favorably for lignin with many of the other products that are commodities; however, competition could increase prices, which

\footnotetext{
7 These data come from NREL's Biomass Scenario Model (BSM). The transport cost varies regionally, and it is calculated endogenously within the BSM. Before proceeding with a project, feedstock quotes should be obtained from local biomass supply vendors to refine biomass costs.

${ }^{8} \mathrm{CF}$ is manufactured from PAN, which is converted into precursor prior to the production of CF. Prepreg is CF fabric that already includes resin.
} 
could potentially reduce cost savings from biomass-based CF. Typically, risk of price increases is hedged through long-term supply contracts in the biomass industry. CF manufacturers could pursue a similar strategy to lock in a raw material supply at a set price that provides revenue certainty for the supplier and manufacturing cost risk mitigation for the CF company.

\section{Integrated Biorefineries}

Another opportunity to reduce risk and costs is for biomass-based CF manufacturing to become part of a broader biorefinery or integrated manufacturing facility. Integrated biorefineries are already a reality in the United States. Figure 6 illustrates the biorefinery projects co-funded by the U.S. Department of Energy's Bioenergy Technologies Office at pilot, demonstration, and pioneer scales, and, as a reference, the existing CF manufacturing plants. Integrated biorefineries use a wide range of biomass resources and conversion technologies to produce biofuels, commodity chemicals, and biopower. They are similar to conventional refineries in that they produce a range of products to optimize production economics and the use of feedstocks (DOE 2014b). Federal support for these first-of-a-kind integrated biorefineries is necessary to validate their performance and significantly reduce the technical and financial risks associated with new technology deployment (DOE 2014b).

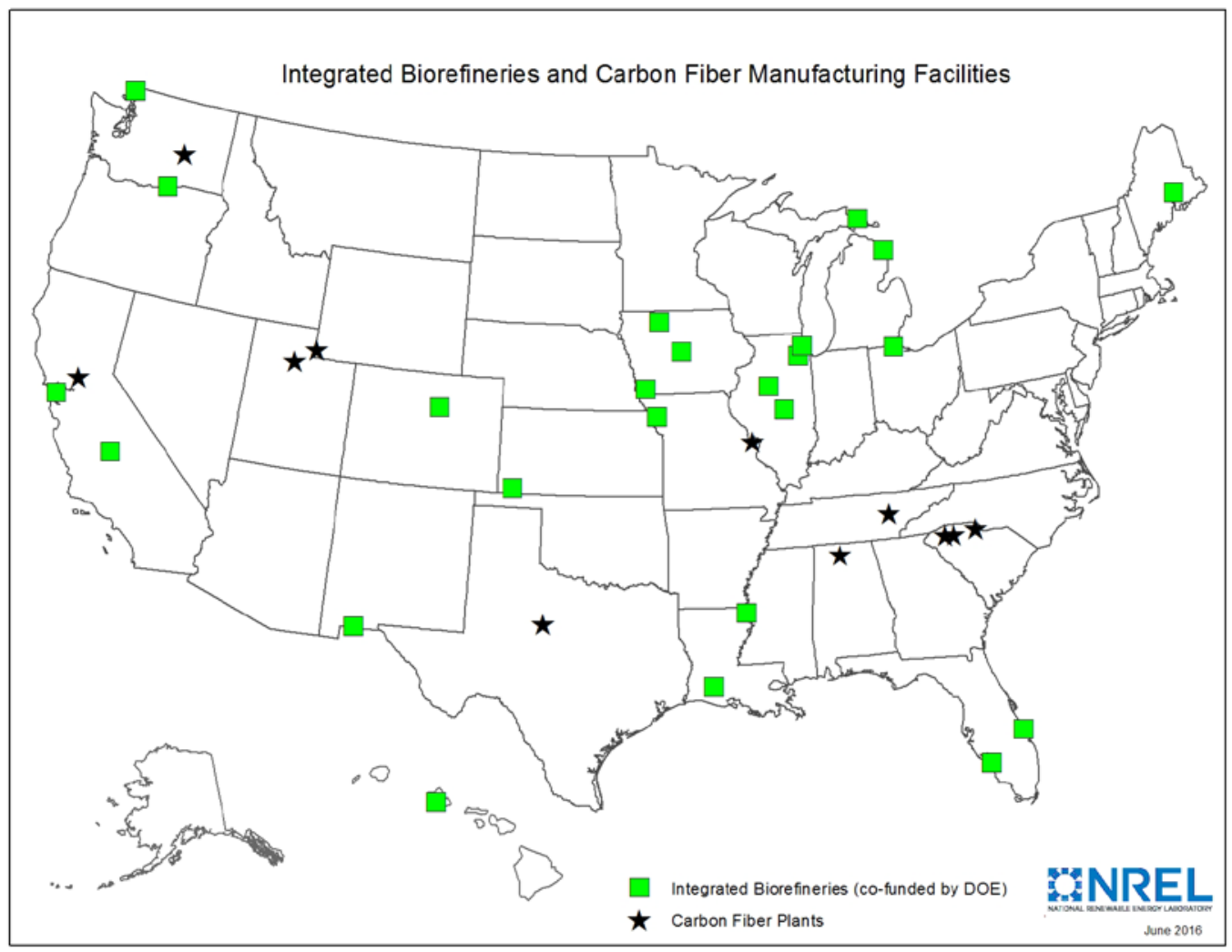

Figure 6. Integrated biorefineries and carbon fiber manufacturing facilities in the United States 


\section{Conclusions}

Our examination of the pathways, technology maturity, opportunities, and barriers for biomassbased CF in the United States leads to the following findings:

- At this time, no biomass-based CF has been developed with the necessary structural properties to be used in the major CF applications (e.g., aerospace, wind, and automotive).

- The physical properties (primarily tensile strength, as well as others) determine the proper application or utilization of the various types of CF that can be developed from biomass sources.

- Rayon-based CF has a limited market share. It is used primarily in insulating and ablative applications because the strength of this type of CF is lower than that required for structural applications.

- Lignin-based CF is currently in the research and development (R\&D) phase. Based on current experimental efforts, the modulus and strength of lignin-based CF are too low to meet structural applications requirements, and thus, current research is focused on non-structural applications such as insulation.

- Glycerol is inexpensive and widely available, but the production of acrylonitrile (ACN) via direct ammoxidation from this resource has been found to be uneconomical at this time; it is about $67 \%$ more expensive than propane-based ammoxidation. Other conversion pathways have been investigated, but their cost effectiveness is yet to be determined.

- CF from lignocellulosic sugars is targeting functionally equivalent material to PAN-based CF. This pathway, currently in the R\&D phase, offers a "drop-in" bio-ACN; thus, it may be more readily commercialized than direct conversion of lignin to $\mathrm{CF}$, which requires the development of new manufacturing operations and hence, a longer commercialization process. However, the development of CF from lignocellulosic sugars faces competition for resources from other industries such as power generation and transportation fuels production.

- In addition to techno-economic viability, biomass-based CF-while potentially desirable from sustainability and cost perspectives - will have many implications and hurdles that need to be considered for manufacturing, feedstock supply, and end products, including material certification, product warranties, competitiveness of products, raw materials, and plant locations.

Our findings are also summarized in Table 3. 
Table 3. Summary Table of Key Findings

\begin{tabular}{|c|c|c|c|c|c|}
\hline $\begin{array}{l}\text { Biomass- } \\
\text { based CF } \\
\text { Precursor }\end{array}$ & $\begin{array}{l}\text { Potential CF } \\
\text { Production } \\
\text { (tonnes/yr) }\end{array}$ & $\begin{array}{l}\text { Technology } \\
\text { Pathway }\end{array}$ & $\begin{array}{c}\text { CF } \\
\text { Production } \\
\text { Cost }\end{array}$ & $\begin{array}{l}\text { Development } \\
\text { Stage }\end{array}$ & $\begin{array}{c}\text { Key } \\
\text { Commercialization } \\
\text { Challenges }\end{array}$ \\
\hline Rayon & $\begin{array}{l}\text { Data not available } \\
\text { (rayon is derived } \\
\text { from cellulose, an } \\
\text { abundant } \\
\text { feedstock) }\end{array}$ & Spinning & $\begin{array}{l}\text { Higher } \\
\text { production } \\
\text { cost than PAN- } \\
\text { based CF }\end{array}$ & $\begin{array}{l}\text { Commercial } \\
\text { (limited) }\end{array}$ & $\begin{array}{l}\text { Low tensile } \\
\text { strength, higher } \\
\text { production cost }\end{array}$ \\
\hline Lignin & 147,500 & Spinning & $\begin{array}{l}\text { \$4-\$6/lb. } \\
\text { (estimated for } \\
\text { commercial- } \\
\text { scale } \\
\text { production) }\end{array}$ & Bench scale & $\begin{array}{l}\text { Low tensile } \\
\text { strength, } \\
\text { manufacturing } \\
\text { limitations, } \\
\text { unproven scale of } \\
\text { commercial } \\
\text { operation }\end{array}$ \\
\hline Glycerol & $\begin{array}{l}\text { Data not available } \\
\text { (about } 575,000 \\
\text { tonnes of glycerol } \\
\text { produced in the } \\
\text { United States in } \\
2015 \text { ) }\end{array}$ & $\begin{array}{l}\text { Direct and } \\
\text { indirect } \\
\text { synthesis }\end{array}$ & $\begin{array}{l}\text { Likely pathway } \\
\text { (direct glycerol } \\
\text { to ACN) about } \\
67 \% \text { more } \\
\text { expensive than } \\
\text { petroleum- } \\
\text { derived PAN }\end{array}$ & Bench scale & $\begin{array}{l}\text { Limited research } \\
\text { (Europe), } \\
\text { higher production } \\
\text { cost (due to } \\
\text { purification needs in } \\
\text { ammoxidation } \\
\text { process) }\end{array}$ \\
\hline $\begin{array}{l}\text { Lignocellulosic } \\
\text { sugars }\end{array}$ & $\begin{array}{l}15,000,000 \\
\text { (from U.S. crop } \\
\text { residues) }\end{array}$ & $\begin{array}{l}\text { Catalytic } \\
\text { conversion, } \\
\text { biochemical } \\
\text { pathways }\end{array}$ & $\begin{array}{l}\text { Target cost of } \\
\text { ACN at } \\
\$ 1.00 / \mathrm{lb} \text {. (the } \\
\text { current cost of } \\
\text { petroleum- } \\
\text { derived } A C N \text { ) } \\
\text { or less, which } \\
\text { equals to CF } \\
\text { of about } \\
\$ 5.00 / \mathrm{lb} \text {. by } \\
2020 \text {. }\end{array}$ & R\&D & $\begin{array}{l}\text { Limited research, } \\
\text { feedstock } \\
\text { competition }\end{array}$ \\
\hline
\end{tabular}




\section{References}

ACS (American Chemical Society). 2003. "High Performance Carbon Fibers." Accessed March 2016. http://www.acs.org/content/acs/en/education/whatischemistry/landmarks/ carbonfibers.html.

Axegard, P., P. Tomani, and H. Hansson. 2013. Road Map 2014 till 2025: Swedish Lignin-Based Carbon Fibre in Composite Materials of the Future. Innventia. Accessed December 2015. http://www.innventia.com/Global/Bilder/Nya\%20material/Road\%20map/Road-map\%2020142025\%20EN\%20final.pdf.

Baker, F. 2010. "Utilization of Sustainable Resources for Production of Carbon Fiber Materials for Structural and Energy Efficiency Applications." Presented at Frontiers in Biorefining: Biobased Products from Renewable Carbon Products, St. Simons Island, Georgia, October 1922. http://www.frontiersinbiorefining.org/2010/Resources/fib-Baker,\%20Fred.pdf.

Bhat, G., S. Akato, N. Cross, W. Hoffman, and F. Mohammadi. 2013. "Recent Developments on Carbon Fiber from Rayon-Based Precursors." Presented at Carbon Fiber R\&D Workshop, Buffalo, New York, July 25-26. Accessed January 2016. http://www.carbonfiberworkshop.com/.

Black, S., and J. Sloan. 2015. “Carbon Fiber 2014 Conference Report." CompositesWorld. March 2, 2015. http://www.compositesworld.com/articles/carbon-fiber-2014-conference-report.

Brice, C. A. 2011. "Unintended Consequences: How Qualification Constrains Innovation." Hampton, VA: National Aeronautics and Space Administration Langley Research Center. http://ntrs.nasa.gov/archive/nasa/casi.ntrs.nasa.gov/20110013659.pdf

Brosius, D. 2014. "What Will Be the Next Major Iteration in Carbon Fiber?" CompositesWorld. September 1, 2014. http://www.compositesworld.com/articles/what-will-be-the-next-majoriteration-in-carbon-fiber.

Casilda, V., M. Guerrero-Perez, and M. Banares. 2009. "Efficient Microwave-Promoted Acrylonitrile Sustainable Synthesis from Glycerol." Green Chemistry 11:939-941.

Chatterjee, S., and T. Saito. 2015. "Lignin-Derived Advanced Carbon Materials." Chem. Sus. Chem. 8(23):3941-3958.

Cláudio, A., M. Neves, K. Shimizu, J. Lopes, M. Freire, and J. Coutinho. 2015. "The Magic of Aqueous Solutions of Ionic Liquids: Ionic Liquids as a Powerful Class of Catanionic Hydrotropes." Green Chemistry 17:3948-3963.

Dahlquist, E. 2013. Biomass as Energy Source: Resources, Systems and Applications. Leiden, The Netherlands: CRC Press, Taylor \& Francis Group.

Das, S., J. Warren, D. West, and S. Schexnayder. 2016. "Global Carbon Fiber Composites Supply Chain Competitiveness Analysis." Clean Energy Manufacturing Analysis Center. May 2016.

Accessed June 2016. http://www.nrel.gov/docs/fy16osti/66071.pdf. 
DOE (U.S. Department of Energy). 2013. Renewable, Low-Cost Carbon Fiber for Lightweight Vehicles. Summary Report from the June 4-5, 2013 Workshop, Detroit, Michigan. http://www1.eere.energy.gov/bioenergy/pdfs/carbon fiber summary report.pdf.

- - - 2014a. “Energy Department Announces \$11 Million to Advance Renewable Carbon Fiber Production from Biomass." July 30, 2014. Energy.gov. http://energy.gov/eere/articles/ energy-department-announces-11-million-advance-renewable-carbon-fiber-production.

- - . 2014b. Integrated Biorefineries: Reducing Investment Risk in Novel Technology. U.S. Department of Energy: Energy Efficiency and Renewable Energy. April 2014. http://www.energy.gov/sites/prod/files/2014/06/f16/ibr portfolio overview.pdf.

- - . 2016. "2016 Billion-Ton Report". Washington, DC, Department of Energy. July 2016. http://energy.gov/sites/prod/files/2016/07/f33/2016 billion ton report 0.pdf

Downing, M. 2013. DOE Lignin to Carbon Fiber Workshop. Presentation at the DOE Lignin to Carbon Fiber Workshop, Detroit, Michigan, June 4. http://www1.eere.energy.gov/bioenergy/pdfs/carbon fiber workshop downing.pdf.

Dumanli, A., and A. Windle. 2012. "Carbon Fibres from Cellulosic Precursors: a Review." Journal of Materials Science 47:4236-4250.

FPInnovations and West Fraser. 2014. "FPInnovations and West Fraser Welcome NRCan Investment Towards Innovative Lignin Separation Process." June 26, 2014. Accessed January 2016. http://www.westfraser.com/sites/default/files/Joint\%20FPI-

WF\%20Lignin\%20Announcement\%20June\%2026\%202014.pdf.

Gabov, K., P. Fardim, and F. G. da Silva Júnior. 2013. "Hydrotropic Fractionation of Birch Wood into Cellulose and Lignin: A New Step Towards Green Biorefinery." BioResources 8(3):35183531.

Gabov, K., R. Gosselink, A. Smeds, and P. Fardim. 2014. "Characterization of Lignin Extracted from Birch Wood by a Modified Hydrotropic Process." J. Agric. Food Chem. 62(44):1075910767.

Gardiner, G. 2014. "Recycled Carbon Fiber Update: Closing the CFRP Lifecycle Loop." CompositesWorld. November 30, 2014. http://www.compositesworld.com/articles/recycledcarbon-fiber-update-closing-the-cfrp-lifecycle-loop.

GraftTech International. 2015. "Carbon Fibers from Sustainable Biomass for Energy Applications." Presented at Composites World Carbon Fiber Conference, Knoxville, TN, December 2015.

Grand View Research, Inc. 2014. "Global Glycerol Market from Biodiesel, Fatty Acids, Fatty Alcohols for Personal Care, Alkyd Resins, Polyether Polyols Applications, Downstream Opportunities is Expected to Reach USD 2.52 Billion By 2020: Grand View Research, Inc." August 2014. http://www.grandviewresearch.com/press-release/global-glycerol-market. 
Green Car Congress. 2014. "DOE to Award up to $\$ 12 \mathrm{M}$ for Technologies to Produce Renewable Carbon Fiber from Biomass." February 4, 2014.

http://www.greencarcongress.com/2014/02/20140204-doecarbon.html.

Guerrero-Perez, M., and M. Banares. 2015. "Metrics of Acrylonitrile: From Biomass vs. Petrochemical Route." Catalysis Today 239:25-30.

Guillon, C., C. Liebig, S. Paul, A. Mamede, W. Hölderich, F. Dumeignila, and B. Katryniok. 2013. "Ammoxidation of Allyl Alcohol: A Sustainable Route to Acrylonitrile." Green Chemistry 15:3015-3019.

Higson, A., and C. Smith. 2011. Lignin. Fact Sheet. NNFCC. Accessed December 2015. http://www.nnfcc.co.uk/publications/nnfcc-renewable-chemicals-factsheet-lignin.

Holladay, J.E., Bozell, J.J., White, J.F., Johnson, D. 2007. Top Value-Added Chemicals from Biomass: Volume II-Results of Screening for Potential Candidates from Biorefinery Lignin. Pacific Northwest National Laboratory. October 2007. http://www.pnl.gov/main/publications/external/technical reports/PNNL-16983.pdf

IETD (Industrial Efficiency Technology Database). n.d. "Alcohol Based Solvent Pulping." Accessed April 2015. http://ietd.iipnetwork.org/content/alcohol-based-solvent-pulping.

Kautto, J., M. Realff, and A. Ragauskas. 2013. “Design and Simulation of an Organosolv Process for Bioethanol Production." Biomass Conversion and Biorefinery 3(3):199-212.

Lake, M., and J. Blackburn. 2014. "SLRP: An Innovative Lignin-Recovery Technology." Cellulose Chem. Technol. 48(9-10):799-804. Accessed December 2015. http://www.cellulosechemtechnol.ro/pdf/CCT9-10(2014)/p.799-804.pdf.

Lake, M., and C. Scouten. 2014. "What Are We Going to Do With all this Lignin?" Presented to Frontiers in BioRefining, St. Simons Island, Georgia, October 24. Accessed December 2015. http://www.frontiersinbiorefining.org/Documents/Session 4B/What\%20To\%20Do\%20With\%2 OAll\%20This\%20Lignin MichaelLake.pdf.

Le Notre, J., E. Scott, M. Franssen, and J. Sanders. 2011. "Biobased Synthesis of Acrylonitrile from Glutamic Acid." Green Chemistry 13:807-809.

Lignoworks. 2015. "What is Lignin?” Accessed April 2015. http://www.icfar.ca/lignoworks/ content/what-lignin.html

Lin, L., Y. Li, and F. Ko. 2013. "Fabrication and Properties of Lignin Based Carbon Nanofiber." Journal of Fiber Bioengineering and Informatics 6(4):335-347.

Liu, Y., H. Tuysuz, C. Jia, M. Schwickardi, R. Rinaldi, A. Lu, W. Schmidt, and F. Schuth. 2010. "From Glycerol to Allyl Alcohol: Iron Oxide Catalyzed Dehydration and Consecutive Hydrogen Transfer." Chemical Communications 46:1238-1240.

Lyons, J. 2014. “Airbus Sets Carbon Fiber Recycling Goal." Environmental Leader. http://www.environmentalleader.com/2014/05/08/airbus-sets-carbon-fiber-recycling-goal/. 
Mäki-Arvela, P., I. Anugwom, P. Virtanen, R. Sjöholm, and J. Mikkola. 2010. “Dissolution of Lignocellulosic Materials and its Constituents Using lonic Liquids: A Review." Industrial Crops and Products 32(3):175-201.

Miller, M., and R. Wool. 2006. "Carbonization of Chicken Feathers for Use in Biocomposites." Presented at the 10th Annual Green Chemistry and Engineering Conference, June 26-30, 2006. https://acs.confex.com/acs/green06/techprogram/P27264.HTM.

- - - 2007. "Carbonization of Chicken Feathers for Use in Biocomposites." Presented at the 11th Annual Green Chemistry and Engineering Conference, June 26-29, 2007. http://acs.confex.com/acs/green07/techprogram/P41563.HTM.

Muhammad, N., Z. Man, and M. Khalil. 2012. "Ionic liquid: A Future Solvent for the Enhanced Uses of Wood Biomass." Eur. J. Wood Prod. 70:125-133.

Omnia LLC. "Assessment of Carbon Fiber Manufacturing Cost: Extract from a Benchmarking Study on Iceland as a Location for Carbon Fiber Production." Invest in Iceland. October 2012. Accessed June 2016. http://www.invest.is/files/skjol/pdff/omnia carbon fiber extract.pdf.

ORNL (Oak Ridge National Laboratory). 2011. 2011 Project Highlights: Lightweighting Materials. Oak Ridge, TN: Oak Ridge National Laboratory. http://web.ornl.gov/sci/ees/transportation/ pdfs/Merged2011Highlights.pdf.

Paper Age. 2011. "Metso to Supply Domtar Mill with First Commercial LignoBoost System." December 15, 2011. Accessed December 2015. http://www.paperage.com/2011news/12 15 2011metso domtar lignoboost.html.

Patent US20100048850 A1. 2010. "Method for the Synthesis of Acrylonitrile from Glycerol." Accessed January 2016. http://appft1.uspto.gov/netacgi/nphParser?Sect1=PTO1\&Sect2=HITOFF\&d=PG01\&p=1\&u=/netahtml/PTO/srchnum.html\&r=1\&f=G \&l=50\&s1=20100048850.PGNR..

Poursorkhabi, V., A. Mohanty, and M. Misra. 2014. "Electrospinning of Aqueous Lignin/Poly (Ethylene Oxide) Complexes." Journal of Applied Polymer Science 132(2). Article first published online August 8, 2014.

RISI. 2013. World Pulp Annual Historical Data: Excerpt. Accessed December 2015. http://www.risiinfo.com/Marketing/ahd/Excerpts/world pulp.pdf.

Rocky Mountain Institute. 2015. "Carbon Fiber Cost Breakdown." Accessed April 2015. http://www.rmi.org/RFGraph-carbon fiber cost breakdown.

Rosas, J., R. Berenguer, M. Valero-Romero, J. Rodríguez-Mirasol, and T. Cordero. 2014. "Preparation of Different Carbon Materials by Thermochemical Conversion of Lignin." Frontiers in Materials 04. Accessed January 2016. http://journal.frontiersin.org/article/ 10.3389/fmats.2014.00029/full.

Schwab, A., Moriarty, K., Milbrandt, A., Geiger, J., Lewis, J. 2016. “2013 Bioenergy Market Report." Prepared by the National Renewable Energy Laboratory. Golden, CO: National Renewable Energy Laboratory. http://www.nrel.gov/docs/fy16osti/63468.pdf. 
Smolarski, N. 2012. "High-Value Opportunities for Lignin: Unlocking its Potential." Frost \& Sullivan. November 7, 2012. Accessed January 2016. http://www.frost.com/sublib/displaymarket-insight-top.do?id=269017995.

Tan, S., D. MacFarlane, J. Upfal, L. Edye, W. Doherty, A. Patti, J. Pringle, and J. Scott. 2009. "Extraction of Lignin from Lignocellulose at Atmospheric Pressure Using Alkylbenzenesulfonate Ionic Liquid." Green Chemistry 11:339-345.

Torrey, IV, W. F., and D. Murray. 2015. An Analysis of the Operational Costs of Trucking: 2015 Update. Arlington, VA: American Transportation Research Institute. September 2015. http://atri-online.org/wp-content/uploads/2015/09/ATRI-Operational-Costs-of-Trucking-2015FINAL-09-2015.pdf.

Traceski, F. (1999). "Assessing Industrial Capabilities for Carbon Fiber Production." Acquisition Review Quarterly. Spring 1999. http://www.dau.mil/pubscats/pubscats/AR\%20Journal/arq99/traceski.pdf.

Tuck, D., and C. Hunter. 2015. "Extracting Lignin for New Forest Products." Natural Resources Canada (NRC). February 2015. Accessed December 2015.

http://www.nrcan.gc.ca/science/story/17110.

U.S. Congress, Office of Technology Assessment. 1989. Technologies for Reducing Dioxin in the Manufacture of Bleached Wood Pulp. OTA-BP-O-54. Washington, D.C.: U.S. Government Printing Office.

Valmet Corporation. 2015. "Valmet-Supplied LignoBoost Plant Now Handed Over to Stora Enso's Sunila Mill in Finland." October 6, 2015. Accessed January 2016. http://www.valmet.com/media/news/press-releases/2015/valmet-supplied-lignoboost-plantnow-handed-over-to-stora-ensos-sunila-mill-in-finland/.

Vanderbilt School of Engineering. 2015. "Simulating Success in Aerospace Manufacturing." March 31, 2015. Accessed January 2016. http://engineering.vanderbilt.edu/news/2015/ simulating-success-in-aerospace-and-automotive-manufacturing/.

Walsh, Paul. 2001. "Carbon Fibers." ASM Handbook, Vol. 21, Composites. Accessed December 2015. http://ansatte.hin.no/ra/MatLinks/carbonfiber overview.pdf.

Warren, C. David. 2011. "Lower Cost Carbon Fiber Precursors." May 2011. Oak Ridge, TN: Oak Ridge National Laboratory. Accessed June 2016. http://energy.gov/sites/prod/files/2014/03/f11/Im004 warren 2011 o.pdf.

- - . 2014. "Development of Low Cost, High Strength Commercial Textile Precursor (PANMA)." June 2014. Oak Ridge, TN: Oak Ridge National Laboratory. http://energy.gov/sites/prod/files/st099_warren_2014_o.pdf.

Wertz, J., and O. Bédué. 2013. Lignocellulosic Biorefineries. Lausanne, Switzerland: EPFL Press. June 27, 2013. 
Willför, S., and J. Gustafsson. 2010. "The Forest Based Biorefinery: Chemical and Engineering Challenges and Opportunities." Accessed December 2015.

http://web.abo.fi/instut/pcc/presentations pdf/Willf\%C3\%B6r Gustafsson Lignin.pdf.

Yang Qin, M. “Acrylonitrile: World Market Overview." Presented at Synthetic Fibres Raw Materials Committee Meeting at APIC 2015, Seoul, May 8, 2015. Tecnon OrbiChem. Accessed June 2016. http://www.apic2015.com/contents/downloads/more/APIC2015 Yang Qin.pdf.

Zhan, M., and R. Wool. 2011. "Mechanical Properties of Chicken Feather Fibers." Polymer Composites 32(6):937-944. 


\section{Appendix A. Sources and Manufacturing of Lignin}

Lignin is the most studied biogenic CF precursor, with more than 50 years of research and significant investments. We provide a more extensive summary of lignin sources and manufacturing below to capture recent developments and progress.

\section{Sources of Lignin}

Sources of lignin include the following commercial and non-commercial processes:

1. Sulfite pulping is a chemical pulping process largely displaced by alkaline (kraft) pulping today. Lignosulfonates, or sulfonated lignin, is isolated from spent sulfite-pulping liquids (red or brown liquor). Lignosulfonates are water-soluble and the most important commercial source of lignin today with global production of about one million tonnes per year (Lignoworks 2015; Higson 2011). The common applications of lignosulfonates are as dispersants, binders, complexing agents, and emulsifying agents (Lignoworks 2015). Today, Borregaard LignoTech, a Borregaard business unit, is the world's largest producer of lignosulfonates (Dahlquist 2013).

2. Kraft (sulfate) pulping is the most widely used chemical pulping process in the world. It uses a combination of high temperature and alkaline chemicals to separate lignin from the cellulose fibers needed for papermaking. The extracted liquid, known as black liquor, contains lignin, hemicellulose, inorganic compounds, and spent cooking chemicals. Lignin is recovered from black liquor through several processes:

A. MeadWestvaco has been recovering lignin from black liquor since the late 1940s in North Charleston, South Carolina, but their process is proprietary and not available for licensing (Lake and Scouten 2014).

B. The LignoBoost process was developed by Innventia in partnership with Chalmers University of Technology (Gothenburg, Sweden). In 2008, Metso acquired the LignoBoost technology from Innventia and the companies have since been working together on the commercialization of the process (Paper Age 2011). In early 2013, the world's first commercial installation of LignoBoost technology began operating at a Domtar mill in Plymouth, North Carolina. The second commercial-scale LignoBoost plant began operating in October 2015 at the Stora Enso's Sunila mill in Finland (Valmet 2015).

C. LignoForce is a proprietary process developed by FP Innovations and NORAM Engineering in the 2000s. A LignoForce demonstration plant in Thunder Bay, Ontario is capable of producing 12.5 kilograms of lignin per hour (FPInnovations and West Fraser 2014). A commercial-scale plant using this technology was to be operational at the West Fraser pulp mill in Hinton, Alberta at the end of 2015; the plant is capable of producing 10,000 tonnes of lignin per year (Tuck and Hunter 2015).

D. The Sequential Liquid-Lignin Recovery and Purification (SLRP) process was developed recently by Liquid Lignin Company in Charleston, South Carolina, with funding from a U.S. Department of Energy Small Business Innovation Research grant. The SLRP process is different from the other processes mentioned above that precipitate lignin as small solid particles that have to be filtered. Instead, it precipitates lignin from black liquor as a true liquid phase that separates by gravity (Lake and Blackburn 2014). The capital and operating costs are estimated to be 
much lower than competitive processes, mainly due to small equipment resulting from SLRP's continuous operation.

Kraft lignin produced commercially (e.g., MeadWestvaco, Metso, and FP Innovations) is used in niche applications such as dispersants for dyes and pesticides (Lignoworks 2015). Other uses include the use of lignin as a renewable replacement for certain glue components used in the manufacture of plywood and engineered wood products such as laminated veneer lumber and oriented strand board (Tuck and Hunter 2015).

An estimated 50 million tonnes of lignin is available annually from the kraft pulping process worldwide, but much of this amount is not isolated and is burned onsite as a low-value fuel (Higson 2011; Smolarski 2012). Higher numbers have also been reported, such as 78 million tonnes per year, assuming 60\% lignin recovery from worldwide pulp production in 2012 (Lake and Scouten 2014; RISI 2013). Currently, commercial kraft lignin (high-purity) is produced by MeadWestvaco and Domtar in the United States (about 60,000 tonnes per year), Stora Enso Sunila mill in Finland (about 50,000 tonnes), and Metso Corporation at a demonstration plant in Backhammar, Sweden (about 4,000 tonnes per year) (Lake and Scouten 2014; Wertz and Bédué 2013; Valmet 2015).

3. Organosolv pulping, also called solvent pulping, is a process using organic solvents (e.g., methanol, ethanol, butanol, and acetic acid) as delignification agents. Solvent pulping offers a potential advantage to traditional kraft pulping in that it can produce high yield and highquality pulp in less cooking time, as well as sulfur-free lignin that is extracted at a much faster rate than the kraft process (IETD, n.d.). However, the high cost of solvents can be cost prohibitive (IETD, n.d.). Several solvent pulping technologies have been developed, but no commercial operations are using them. These include CIMV's Biolignin (France), Lignol Innovations' Alcell (Canada), University of California-Riverside's Co-solvent Enhanced Lignocellulosic Fractionation (CELF) method using tetrahydrofuran (THF), University of Wisconsin-Madison's method using gamma valerolactone (GVL) as a biomass-derived solvent, and others.

The Organosolv process has been considered a pretreatment step in cellulosic ethanol production. In addition to producing ethanol (which is produced via enzymatic hydrolysis of cellulose to glucose followed by fermentation), Organosolv pulping allows for the production of pure lignin and other co-products (Kautto et al. 2013). Cellulosic ethanol is now being produced commercially in Europe (e.g., M\&G facility in Crescentino, Italy), in the United States (POET/DSM plant in Emmetsburg, lowa; Abengoa plant in Hugoton, Kansas; and DuPont plant near completion in Nevada, lowa), and in Brazil (GranBio plant in Alagoas). As cellulosic ethanol production increases over time and the concept of "integrated biorefinery" (capable of producing a range of products to optimize the use of biomass resources and production economics) becomes a reality, it is expected that large quantities of lignin will be produced with higher quality and greater commercial value than lignin from chemical pulping (sulfite and kraft).

4. Hydrotropic pulping is a process that uses concentrated aqueous solutions of hydrotropic agents (salts that, at high concentration, considerably improve the aqueous solubility of poorly soluble substances) at elevated temperatures (Gabov et al. 2014). This process was extensively studied from the 1950 s through 1980 s as an alternative to traditional sulfite and kraft methods (Gabov et al. 2013). Some of the advantages listed for this process include higher cellulose yield, lower capital costs, heat savings, and simplicity of the process in comparison to kraft pulping (Willför and Gustafsson 2010). Unlike sulfite or kraft pulping, 
which uses contaminating inorganic chemicals, the lignin recovered through precipitation by hydrotropic pulping is relatively pure and is suitable for conversion to other chemical products (U.S. Congress 1989). Recent experiments show that hydrotropic lignin is similar to Organosolv lignin, which is of high quality (Gabov et al. 2014). However, the hydrotropic process is unsuitable for softwood (e.g., pine, fir, and spruce), which is the primary reason it has received limited attention from the industry (U.S. Congress 1989). Increasing demand for bio-based products may bring this option back into consideration, especially given recent efforts in growing woody crops (e.g., hardwood species such as poplar and willow) for energy. Also, efforts continue in this area and research on the use of ionic liquids (a new class of powerful catanionic hydrotropes) has proven successful for hardwood and softwood species as well as non-woody biomass such as sugarcane bagasse (Tan et al. 2009; Cláudio et al. 2015; Muhammad et al. 2012; Mäki-Arvela 2010).

\section{Manufacture of Lignin Fibers}

The manufacturing cost and the final morphology and properties of lignin-based CF depend not only on the precursor chemistry and extraction technique but also on the fiber processing methodology (Rosas et al. 2014). Spinning is the manufacturing process for creating polymer fibers. Various spinning methods have been explored for lignin, namely wet-, dry-, melt-, and electrospinning.

Lignin-based CF by dry- and wet-spinning (both methods require soluble lignins) were extensively researched in the 1970s, but the process almost ceased in the 1980s (Rosas et al. 2014). Lignin-based CF via melt-spinning (in which lignin is pelletized and the pellets are melted, extruded, and then solidified by cooling) has been most studied during the last two decades because of its economic advantages over other methods (e.g., no solvents are needed). There are some challenges associated with melt-spinning of lignin that are still being researched. For example, while hardwood lignin melt spins well, it stabilizes slowly and while softwood lignin stabilizes well, it does not readily melt spin (Downing 2013). Also, high-purity lignin is needed for melt-spinning. Electrospinning (in which polymer solution is injected in an electrical field to produce nano- to micro-diameter fibers) has emerged in recent years as a promising method for preparing novel lignin-based fibrous materials (Poursorkhabi et al. 2014; Rosas et al. 2014). 